\title{
ISOLATION, CHEMICAL COMPOSITION, CHARACTERIZATION AND ANTI-BACTERIAL ACTIVITY OF ACRIDINE DIGLYCOSIDE FROM MORINGA OLIFERA
}

\author{
Ikpa, Chinyere Benardette Chinaka ${ }^{1 \mathrm{a}}{ }^{*} \mathrm{Ibe}$, Francis Chizoruo ${ }^{1 \mathrm{~b}}$ \\ and Ikpa, Chinomnso Uzoamaka ${ }^{2 \mathrm{c}}$ \\ ${ }^{1}$ Departement of Chemistry. Imo State University P.M.B 2000, Owerri, Imo State Nigeria. \\ ${ }^{2}$ Department of Biochemistry. Michael Okpara University of Agriculture, Umudike, Umuahia, Abia \\ State, Nigeria. \\ E-mail address: ${ }^{a i k p a c b c ~ @ g m a i l . c o m, ~ * b i b e f r a n c i s @ i m s u . e d u . n g, ~}{ }^{c}$ chinomnso.ikpa@gmail.com.
}

Keywords: Moringa olifera, Phytomedcine, Nutritional nutrients, Infections, Anti-inflamatory, Acridine diglycoside.

\begin{abstract}
Moringa olifera (drumstick tree) is a medicinal plant commonly used in phytomedicine to cure and prevent diseases in Nigeria. The ethanolic extract of the leave sample showed alkaloid $\{(9.66 \pm 0.20) \%\}$, phenols $\{(0.75 \pm 0.22) \%\}$, flavonoids $\{(6.86 \pm 0.20) \%\}$, saponines $\{(8.46 \pm$ $0.10) \%\}$, and tannins $\{(1.10 \pm 0.20) \%\}$. The plant also contains nutritional nutrients such as ash $\{(6.08 \pm 0.02) \%\}$, protein $\{(23.65 \pm 0.12) \%\}$, carbohydrates $\{(57.01 \pm 0.01) \%\}$, fats $\{(2.43 \pm 0.01)$ $\%\}$, crude fibre $\{(6.02 \pm 0.13) \%\}$, moisture $\{(9.50 \pm 0.10) \%\}$ and energy $\{(3276 \pm 0.14) \%\}$. Antibacterial studies showed that the plant leave successfully inhibited staphylococcus aureus, Escherichia coli, Pseudomonas aeruginosa, Proteus mirabilis and Klebisiella pneumonia. Acridine diglycoside was elucidated using Bruker NMR spectroscopy in combination with FT-IR NATRIC and HREIMS $(\mathrm{m} / \mathrm{z})$ mass spectral data. This result authenticates the use of the plant leave in the treatment of infections, tumors and as an anti-inflammatory agent
\end{abstract}

\section{Introduction}

Moringa oleifera, the most widely cultivated species of moringa plants is a multipurpose tree cultivated throughout the tropics [1]. M.olifera, commonly known as drumstick tree, horseradish tree or benzoil tree [2] is used in herbal medicine and can also be used for water purification and hand washing [3]. M. oleifera is used as an alternative source for nutritional supplements and growth promoters in some countries [4]. Apart from nutritional benefits, M. Oleifera has been reported to be used for the treatment of rheumatism, ascites, infection, hiccough influenza and internal abscess [5].

The leaf extract is capable of reducing hyperglycaemia, cholesterol lowering [9], and dyslipidemia [6]. Important medicinal properties of the $M$. olifera which have been recently reported include antipyretic, antiepileptic, anti-inflammatory, anti-ulcerative [7], anti-hypertensive [8], anti-oxidant [10], anti- diabetic, hepatoprotective [11], anti-bacterial and anti-fungal activities [10]. In addition, M. oleifera seed possesses water purifying power $[12,13]$. The plant species have long been recognized by folk medicine practitioners as having value in the treatment of tumours [14]. The edible Moringa leaves contain essential provitamins, including ascorbic acid and carotenoids [15]. Various parts of the plant such as the leaves, roots, seed, bark, fruit, flowers and immature pods act as cardiac and circulatory stimulants, and also possesses anti-tumour agents [16].

\section{MATERIAL AND METHODS}

Plant materials. Matured leaves sample were harvested in a garden at Umezeala Nsu in Ehime Mbano of Imo State on December $30^{\text {th }}$ 2014. Authentication of the plant was done at taxonomy section of Forestry Department of Michael Okpara University of Agriculture Umudike Nigeria. 
Extraction and isolation of the plant sample was done by drying the leaves at room temperature for two weeks. The leaves were grounded to powder and stored in an amber bottle. Phytochemicals and proximate analysis were done with some of the powdered leave sample, while the rest were percolated with $2 \mathrm{~L}$ of ethanol for four days. The extract was filtered and concentrated with rota at $35^{0} \mathrm{C}-40^{0} \mathrm{C}$.

Proximate analysis. Moisture content of the sample was determined using the method described by AOAC [17]. One gram of sample in pre-weighed crucible was placed in an oven $\left(105^{\circ} \mathrm{C}\right)$ for $24 \mathrm{~h}$, cooled, and reweighed. The percentage moisture was calculated as follows: Moisture $(\%)=\mathrm{w}_{2}-\mathrm{w}_{3}$ $\mathrm{w}_{2}-\mathrm{w}_{1} \times 100\left(\mathrm{w}_{1}=\right.$ weight of the crucible, $\mathrm{w}_{2}=$ weight of the crucible and sample after drying, and $\mathrm{w}_{3}=$ weight of the crucible and the sample after cooling in airtight desiccators.

The ash content was determined using a weighed $(1.0 \mathrm{~g})$ sample which was subjected to dry ashing in a well cleaned proclaim crucible at $550^{\circ} \mathrm{C}$ in a muffle furnace for 2 hours. The ash percentage was calculated as follows: Ash $(\%)=w 2-w 3 / w 2-w 1 \times 100$. Where, $w 1=$ weight of the crucible, $\mathrm{w}_{2}$ is the weight of the crucible and sample ash at $550^{\circ} \mathrm{C}$, and $\mathrm{w}_{3}=$ weight of the crucible and the sample ash after cooling in airtight desiccators [18].

Crude protein was determined using the micro-Kjeldahl method as reported by Fahey [18]. The crude protein was calculated by multiplying nitrogen with the conversion factor of $6.25[\mathrm{P} \%=$ TN x 6.25]. Fat content was determined using the method described by Folch, and Stanley [19]. Homogenized tissue $(10 \mathrm{~g})$ was progressively added to small amounts of a chloroform/methanol 2:1 (v/v) mixture (up to $200 \mathrm{ml}$ ), with vigorous shaking, and then the extraction was carried on for a further 2 hours, using an electromagnetic stirrer. The mixture was filtered and the filter was rewashed with fresh solvent and pressed. Fifty millilitres of $0.88 \%$ potassium chloride were added and the mixture was shaken. The aqueous layer (upper) was removed by aspiration and the washing procedure was repeated. The extract was then dried by adding anhydrous sodium sulphate, which was filtered again before the solvent was removed using a rotary evaporator. The extract was then placed in desiccators overnight and weighed.

Crude fibre was determined using $1.0 \mathrm{~g}$ of sample $\left(\mathrm{W}_{2}\right)$ which was transferred directly into a filter bag and sealed with a heat sealer. Sample and blank bags were immersed in enough amount petroleum ether for 10 minutes to extract fat content from samples. All bags were air dried and transferred to a Ankom 2000 Fiber Analyzer using $\mathrm{H}_{2} \mathrm{SO}_{4}$ and $\mathrm{NaOH}$ and the crude fibre was calculated according to the following equation: \% Crude fibre $=100 \times\left(\mathrm{W}_{3}-\left(\mathrm{W}_{1} \times \mathrm{C}_{1}\right)\right) / \mathrm{W}_{2} \mathrm{Where}$ $\mathrm{W}_{1}=$ Bag tare weight $\mathrm{W}_{2}=$ Sample Weight $\mathrm{W}_{3}=$ Weight of Organic matter (Loss of weight on ignition of bag and fibre) $\mathrm{C}_{1}=$ Ash corrected blank bag factor (running average of loss of weight on ignition of blank bag/original blank bag) [20].

Carbohydrate content was determined by difference, that is, addition of all the percentages of moisture, fat, crude protein, ash, and crude fibre were subtracted from $100 \%$, while the sample energy value was estimated (in $\mathrm{KCal} / \mathrm{g}$ ) by multiplying the percentages of protein, lipid, and carbohydrate [21].

Phytochemical evaluation.The M. olifera plant leave sample was evaluated for alkaloids and phenols according to Harbon [22]. While flavonoids were evaluated as described by Boham [23]. The method described by Van-burden and Robinson was adopted for the determination of tannins [24]. Saponines were determined as reported by Obadoni [25].

\section{FRACTIONAL SEPARATION OF THE COMPOUNDS}

The concentrated ethanol was dried to obtain dark green gummy crude extract and a portion was partitioned between chloroform and water to obtain chloroform and water fractions. The dried chloroform fraction was partitioned between methanol and petroleum ether. The possible number of compounds in each fraction was determined using TLC. Methanol fraction showed the highest zone of inhibition in antibacterial activity and was subjected to column chromatography over silica gel Merck grade (60-120 mesh). The labelled eluted fractions were analysed with TLC and fraction M6 
which is a dark green oil gave one spot with $R_{f}$ value of 0.74 . The pure dark green oil was further analysed and found to be acridine diglycoside using IR Perkin Elmer model 760. The mass was determined with HREIMS positive ion mode using Bruker multinuclear NMR experiments of ${ }^{1} \mathrm{H}$ and ${ }^{13} \mathrm{C}$.

\section{EVALUATION OF ANTIBACTERIAL ACTIVITY OF M. OLEIFERA LEAVES}

Preparation of the inoculums. The standard clinical isolated organisms of Pseudomonas aeruginosa (P. Aeruginosa), Staphylococcus aurous (Staph), Escherichia coli (E-coli), klebsiella pneumonia (Kleb) and Proteus mirabilis (Proteus) were obtained from Federal Medical Centre, Owerri and the analysis was carried at Department of Medical Science Laboratory Imo state University. The strains of the organisms were propagated on nutrient agar plates and maintained at $4^{0} \mathrm{c}$. The isolates were sub-cultured in nutrient broth at $37^{\circ} \mathrm{C}$ for $8 \mathrm{~h}$ prior to antibacterial testing.

Antibacterial sensitivity testing of compounds. Agar well diffusion technique was used to determine the antibacterial activity of the fractions of the leave sample. Sensitivity test of the agar plates were by inoculating with $0.1 \mathrm{ml}$ of an overnight culture of each bacteria strain (equivalent to $10^{8} \mathrm{CFU} / \mathrm{ml}^{-1}$ ). The inoculated agar plates were allowed to dry and were appropriately labelled. Using a plastic cork borer of $6 \mathrm{~mm}$ in diameter uniformed wells was bored in the inoculated nutrient agar. With a micropipette, $300 \mu 1$ of $20 \mathrm{mg} / \mathrm{ml}$ of each fraction of the leave sample was delivered into each well. The plates were left on the bench for 30 minutes to allow the compound to diffuse into the agar. Thereafter, the plates were incubated at $37^{\circ} \mathrm{C}$ for 24 hours. After incubation, the plates were observed for inhibition zones around the wells. The diameters of the zones were measured with metre rule to the nearest whole millimetre [26].

\section{RESULTS AND DISCUSSION}

The results of proximate analyses (in \%) as shown in table 1 indicates that the Moringa oleifera leaves contains carbohydrate $(57.01 \pm 0.01)$, protein $(23.65 \pm 0.12)$, fats $(2.43 \pm 0.01)$, moisture

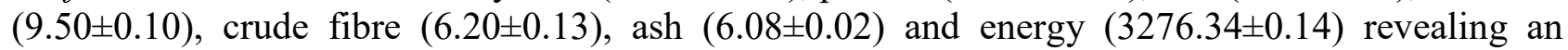
excellent source of nutrition and natural energy which can be used as a good nutritional supplements.

Table 1: Proximate composition of M.Oleifere leaves

\begin{tabular}{ll}
\hline Nutrient & Composition[\%] \\
\hline Ash & $6.08 \pm 0.02$ \\
Protein & $23.65 \pm 0.12$ \\
Carbohydrate & $57.01 \pm 0.01$ \\
Fats & $2.43 \pm 0.01$ \\
Crude Fibre & $6.02 \pm 0.13$ \\
Moisture & $9.50 \pm 0.10$ \\
Energy & $3276 \pm 0.14$ \\
\hline
\end{tabular}

Value $=$ SD of triplicate values

Table 2: Phytochemical analysis of M.Oleifere leaves.

\begin{tabular}{ll}
\hline Phytochemical & Percentage composition [\%] \\
\hline Alkaliod & $9.66 \pm 0.20$ \\
Phenols & $0.75 \pm 0.22$ \\
Flavoniods & $6.86 \pm 0.20$ \\
Saponine & $8.46 \pm 0.10$ \\
Tannins & $1.10 \pm 0.20$ \\
\hline
\end{tabular}

Value $=$ SD of triplicate values 
The result of phytochemical analysis of M.oleifere leaves is presented in table 2. The high percentage of alkaloids, flavonoids and saponini contents of M.Oleifera supports the use of the plant leaves for the treatment of bacterial infections, allergies, inflammation, tumour, viruses and cancer [27].

Table 3: Anti-bacterial Activities of M.Oleifera with $300 \mu 1$ of $20 \mathrm{mg} / \mathrm{ml}$.

Zone of Inhibition of the fractions in [mm]

\begin{tabular}{llllll}
\hline Fractions & P.Aeruginosa & Staph & E-Coli & Kleb & Proteus \\
\hline Chloroform & 4 & 6 & 12 & 4 & - \\
Ethanol & 14 & 14 & 14 & 14 & 14 \\
Methanol & 12 & 16 & 14 & 16 & 12 \\
Pet-ether & 4 & 14 & 4 & 4 & 4 \\
\hline
\end{tabular}

Value $=$ SD of triplicate values

Results of anti-bacterial activities of M.oleifera is presented in table 3.The anti-bacterial activity showed that the ethanol and methanol fractions showed higher zone of inhibition (in $\mathrm{mm}$ ) than other fractions. The result supports the use of M.oleifera for the treatment of wound [28], which justifies the traditional use of M.oleifera in herbal treatments [3].

Table 4: NMR assignment Analysis of M.oleifera

\begin{tabular}{lllll}
\hline Assignment & $\boldsymbol{\delta}^{\mathbf{1 3}} \mathbf{C}$ & Multiplicity & $\boldsymbol{\delta}^{\mathbf{1}} \mathbf{H}$ & Integral Value \\
\hline 1 & 116.69 & $\mathrm{~S}$ & 7.25 & 1 \\
2 & 135.25 & $\mathrm{~T}$ & - & - \\
3 & 116.68 & $\mathrm{~S}$ & 7.50 & 1 \\
4 & 115.20 & $\mathrm{~S}$ & 7.06 & 1 \\
5 & 187.01 & $\mathrm{D}$ & - & - \\
6 & 117.00 & $\mathrm{~S}$ & 7.00 & 1 \\
7 & 135.20 & $\mathrm{~T}$ & - & - \\
8 & 115.21 & $\mathrm{~S}$ & 7.75 & 1 \\
9 & 86.72 & $\mathrm{Q}$ & - & - \\
10 & - & - & - & - \\
11 & 42.05 & $\mathrm{~S}$ & 1.47 & 3 \\
12 & 80.28 & $\mathrm{D}$ & 1.75 & 1 \\
13 & 80.30 & $\mathrm{M}$ & 1.50 & 1 \\
14 & 45.02 & $\mathrm{D}$ & 0.90 & 3 \\
15 & 112.21 & $\mathrm{~S}$ & 2.25 & 1 \\
16 & 112.76 & $\mathrm{~S}$ & 2.02 & 3 \\
A & 140.08 & $\mathrm{~S}$ & - & - \\
B & 172.87 & $\mathrm{D}$ & - & - \\
C & 172.89 & $\mathrm{~S}$ & - & - \\
$\mathrm{D}$ & 140.02 & $\mathrm{D}$ & - & - \\
Sugar & $92.45-102.21$ & - & $2.40-5.50$ & - \\
\hline
\end{tabular}

The column chromatography gave dark green oil with $\mathrm{R}_{\mathrm{f}}$ of 0.74 on TLC. Its mass 613 was determined by HREIMS of $(612.54 \mathrm{~m} / \mathrm{z})$ and calculated for $\mathrm{C}_{31} \mathrm{H}_{39} \mathrm{~N}_{2} \mathrm{O}_{11}$.

The IR spectrum exhibited absorptions (in $\mathrm{cm}^{-1}$ ) at 3358.79 (NH stretching), 2919.12 (C-H stretching), $2158.85(\mathrm{~N}-\mathrm{C}=\mathrm{N})$ and $1711.51(\mathrm{C}-\mathrm{O}-\mathrm{Ar})$

Table 4 is the NMR analysis of M.oleifera. The $\mathrm{H}^{1}$ NMR spectrum of compound I showed aromatic

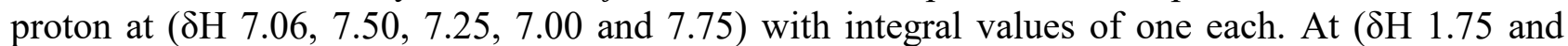
$1.50)$ are methylene protons with integral value of one each and methyl protons at $(\delta \mathrm{H} .0 .90$ and $1.47)$, methyl proton with nitrogen linkage at $(\delta \mathrm{H} .2 .02)$. Table 4 indicates that ${ }^{13} \mathrm{C}$ NMR showed signals of aromatic C-H carbon at $\left(\delta \mathrm{C} 115.20_{(\mathrm{s})}, 116.68_{(\mathrm{s})}, 116.69_{(\mathrm{s})}, 117.00_{(\mathrm{s})}, 115.21_{(\mathrm{s})}\right.$, aromatic 
quaternary carbon at $\left(\delta \mathrm{C} .135 .23_{(\mathrm{t})}, 172.87_{(\mathrm{d})}, 86.72_{(\mathrm{q})}, 172.89_{(\mathrm{s})}, 187.01_{(\mathrm{d})}, 135.20_{(\mathrm{t})}\right.$. C-H with nitrogen linkage at $\left(\delta \mathrm{C} .112 .21_{(\mathrm{s})}\right.$, Methylene carbon $(\mathrm{C}=\mathrm{C})$ at $\left(\delta \mathrm{C} 80.30_{(\mathrm{m})}\right.$ and $80.28(\mathrm{~d})$, Saturated methyl carbon at $\left(\delta \mathrm{C} .42 .5_{(\mathrm{s})}\right.$ and $45.02_{(\mathrm{d})}$ and Methyl carbon with N-linkage at $\left(\delta \mathrm{C} .112 .76_{(\mathrm{s})}\right.$. Qauntinary carbon with Het. N-linkage at $\left(\delta \mathrm{C}: 140.08_{(\mathrm{s})}\right.$ and $140.02_{(\mathrm{d})}$ The data in table 4 and the elucidated structure (compd 1) below showed that the compound is an Acridine diglycoside(compd $1)$.

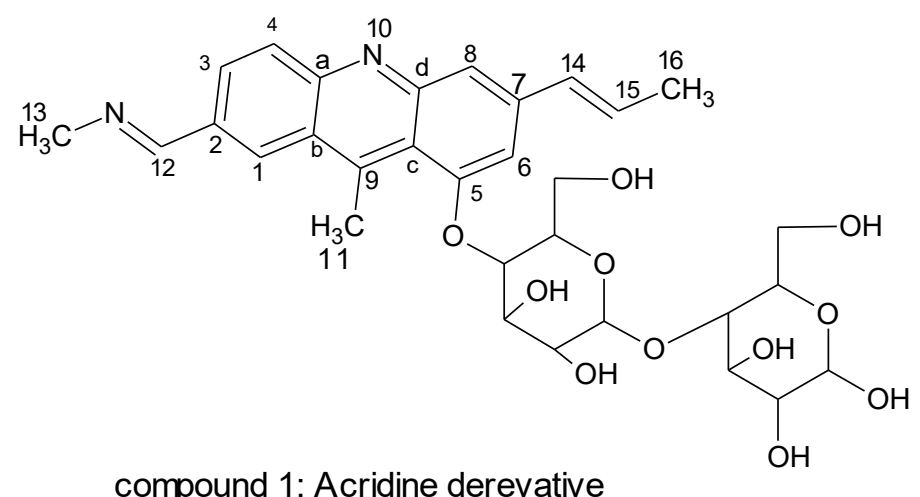

The presence of acridine derivatives which acts as anti-bacterial, anti-parasitic and anti-cancer agents [29], supports the use of M.Oleifera in the treatment of bacterial, parasitic infection [10], cancer and viral attacks $[7,14]$. The isolated compound Acridine diglycoside can be used by pharmaceutical firms for drug formulation.

\section{Conclusion}

This work showed that M. Olifera is an all-purpose plant. The leaves have very high nutritional value and a good source of protein, fiber, carbohydrate, fats and energy. M olifera is very important for its many impressive ranges of medicinal uses. Antibacterial studies of the plant leave proved that it could successfully inhibit the growth of staphylococcus aureus, escherichia coli, pseudomonas aeruginosa, proteus mirabilis and klebisiella pneumonia. The isolated compound Acridine diglycoside, which was elucidated with Bruker NMR spectroscopy in combination with FT-IR NATRIC and HREIMS (m/z) mass spectral data could be used by pharmaceutical by firms for drug formulation

\section{REFERENCES}

[1] J. Janick and E. P.Robert, The Encyclopedia of Fruit \& Nuts. CABI. (2008)

[2] M. E. Olson, Flora of North America Editorial Committee, ed. Moringaceae: Drumstick Family. Flora of North America North of Mexico 7. New York and Oxford. (2010)

[3] A. Leone, A. Spada, A. Battezzati, A. Schiraldi, J. Aristil and S.Bertoli, Cultivation, Genetic, Ethnopharmacology, Phytochemistry and Pharmacology of Moringa oleifera Leaves, An Overview"_ Int J Mol Sci, 16 (6) (2015) 12791-835.

[4] F. Anwar, S, Latif, M. Ashraf and AH, Gilani., "Moringa oleifera: A food plant with multiple medicinal uses". Phytother. Res. 21 (2007) 17-125.

[5] G. Mishra, P. Singh, R. Verma, S. Kumar, S. Srivastav, K.K. Jha and R. L. Khosa, Traditional uses, phytochemistry and pharmacological properties of Moringa oleifera plant. An overview, DerPharmacia Lettre 3 (2011) 141-164.

[6] M. Mbikay, Therapeutic potential of Moringa oleifera leaves in chronic hyperglycemia and dyslipidemia. A review. Front. Pharmacol. 3 (2012) 1-12.

[7] S.K. Pal, P.K. Mukherjee, and B.P. Saha, Studies on the antiulcer activity of M. oleifera leaf extract on gastric ulcer models in rats, Phytother. Res. 9 (1995) 463 - 465. 
[8] M.U. Dahot, Vitamin contents of flowers and seeds of M. Oleifera, Pak. J. Biochem. 21 (1988) $1-24$.

[9] L.K. Mehta, R. Balaraman, Amin, A.H., Baffa, P.A. and O.D. Gulati, Effects of fruits of M. oleifera on the lipid profile of normal and hypercholesterolaemic rabbits. J. Ethnopharmacol. 86 (2003) $191-195$.

[10] F. Nickon, Z.A. Saud, M.H. Rehman and M.E. Haque, In vitro antimicrobial activity of the compound isolated from chloroform extract of M. Oleifera. Lam. Pak. J. Biol. Sci. 22 (2003) $1888-1890$.

[11] K. Ruckmani, S. Kavimani, R. Anandan and B. Jaykar, Effect of Moringa oleifera Lam on paracetamol - induced hepatoxicity. Indian J. Pharm. Sci. 60 (1998) 33 - 35.

[12] A.H. Kawo, Water purification potentials and in-vivo toxicity evaluation of the aqueous and petroleum ether extracts of Calotropis procera (Ait.F) Ait.F. latex and Moringa oleifera Lam seed powder. PhD thesis, Microbiology Unit, Department of Biological Sciences, Bayero University, Kano. (2007)

[13] S.Y. Daniyan, M.E. Abalaka and O.E. Eru, The use of Moringa seed extract in water purification. International Research Journal in Ayurveda \& Pharmacy. 2(4) (2011) 1265-1271.

[14] R. Gupta, G.M Kannan, M. Sharma, S.J.S. Flora, Therapeutic effects of Moringa oleifera on arsenicinduced toxicity in rats. Environmental Toxicology and Pharmacology. 20(3) (2005) 456-464.

[15] J. Lako, V.C. Trenerry, M. Wahlqvist, N. Wattanapenpaiboon, S. Southeeswaran, R. Premier, Phytochemical flavonols, carotenoids and the antioxidant properties of a wide selection of Fijian fruit,vegetables and other readily available foods, Food Chemistry 101(4) . (2007)1727-1741.

[16] E. Makonnen, A. Hunde, and G. Damecha, Hypoglycaemic effect of M. stenopetala aqueous extract in rabbits. Phytother. Res. 11 (1997) $147-148$.

[17] AOAC., Official Methods of Analysis, Association of Official analytical Chemists. Washington DC, USA (1995).

[18] J. Fahey, Moringa oleifera: A review of the Medical Evidence for its Nutritional, therapeutic and Prophylactic Properties Part 1, Trees for Life Journal. 1(2005) 5-10.

[19] J.M. Folch, G.H.S. Stanley, A simple method for the isolation and purification of total lipids from animal tissues. Journal of Biological Chemistry, 226 (1957) 497-509.

[20] AOAC Official Methods of Analysis, 17th Ed., Association official Analytical Chemists. Washington DC, USA. (2005).

[21] E.A. Martin, A.A Coolidge., Nutrition in action. $4^{\text {th }}$ ed. Holt, R and Wilson Co publishers New York, (1978).

[22] J.B. Harbon, Phytochemical methods of chapman and Hall, London, (1973); pp 110-113.

[23] B.A. Boham and Kocipai A.C., Flavonoid and condensed tannins from leaves of hawalian vaccinium vaticulatum and V. Callicinium. Pacific science 48 (1974) 458-463.

[24] T.P Van-burden, and W.C. Robinson, Formation of complexes between protein and tannin acid. J. Agric Food Chem (1) (1981) 77-82

[25] B.O Obadoni, and P.O. Ochuko, Phytochemical studies and comparative efficacy of the crude extracts of some homeostatic plants in Edo and Delta state of Nigeria . Global Journal of pure and Applied Sciences 8 (2001) 203-208.

[26] Adeniyi, B.A; Odelola, H.A., “Anti-microbial potentials of Diospyros mespiliformis”. African journal of medicinal science, 255 (I996) 221-224. 
[27] D.E. Okwu, and I.N. Emenike, Evaluation of the Phytonutrients and Vitamins Content of Citrus Fruits. International J. Molecular Med. Adv. Sci., (2006) 2(1),1-6

[28] R.N Okigbo, O.D. Omodamiro, Anti-microbial effects of leaf extracts of pigeon pea on human pathogens. J. Herbs, species Med. Plants. 12 (2006) 117-127.

[29] B. Philip. B. John, G. Thomas and T. Martin, Anti -cancer agents. J of medicinal chemistry (2) (2016) 139-169. 